\title{
A Quest to Survey Library and University Press Collaborations in Canada: A Case Study in Research Approach and Design
}

Rosarie Coughlan, Scholarly Publishing Librarian, Queen's University Library

Geoffrey Brown, Digital Scholarship Librarian, Dalhousie University

Robert Glushko, Associate Chief Librarian, Western University

Inba Kehoe, Copyright Officer, Scholarly Communication Librarian, University of Victoria

\section{Introduction}

This paper explores a failed research project to undertake an online survey of Canadian university presses. We begin by summarizing the project, we then offer four practical reflections on why our research project was abandoned and how we might have approached the project differently (given the benefit of hindsight) that might have afforded a more positive outcome. We hope that this reflective critique will provide valuable lessons to both the researchers and others, when considering effective research design methodologies and approaches to engage the proactive involvement of a cross-sectoral group of survey participants.

\section{About the Project}

In spring 2015, the Canadian Association of Research Libraries (CARL) tasked its Open Access Working Group (OAWG) ${ }^{1}$ with surveying Canadian university presses in order to gain insight into current publishing practices as well as publisher attitudes towards evolving business models in the face of a rapidly changing publishing landscape. The group sought to gather valuable data about current challenges facing the Canadian scholarly publishing industry, and future opportunities for ongoing collaboration between libraries and 
university presses in Canada.

In order to conceptualize both the format and rationale for undertaking the survey, the overarching research questions to be addressed in the project, as well as the key variables defining the specific survey questions that would be posed to the sample population, the research group undertook a comprehensive literature review. This review focused on current research on monograph publishing, with a focus on financial and business models for dissemination, including case studies, theoretical models, and research articles. The project sought to explore the following research questions:

1. What alternative and/or open access publishing business models are currently being used for monograph publishing by Canadian university presses, and have any of these proven to be successful?

2. Of the publishing and funding models identified, which might Canadian university presses likely embrace to facilitate greater dissemination of published works that is both sustainable and economically sound?

3. How might university libraries and university presses work towards establishing new collaborative approaches to publishing scholarly monographs in Canada?

The working group designed the survey in the tradition of surveys undertaken by the American Association of University Presses (AAUP), specifically the Press and Library Collaboration survey (AAUP Library Relations Committee). ${ }^{2}$ Our survey was administered to the sample population in spring 2015, with a two-month completion window. Each recipient received a personalized email invitation accompanied by a detailed outline of the provenance and rationale for the survey, information about the researchers (names, affiliations), the project objectives and intended methods of dissemination, as well as a link to a Consent Agreement form. The survey instrument was a standardized online questionnaire created using SurveyMonkey, an online survey tool. A link to participate was embedded in the invitation. This 
approach has a number of advantages, including ease of distribution and analysis and the potential to receive more candid responses as respondents could complete the survey voluntarily and anonymously.

\section{The Research "Failure"}

The primary participant groups invited to complete the survey included Canadian university press directors and library press directors. The former group declined the invitation to participate in the survey for two reasons:

1. They felt that the survey invitation indicated a presumption on the part of the research group, towards an open access business model for monograph publishing in Canada, which implied a bias in any recommendations resulting from the project.

2. They expressed regret at not having the opportunity to contribute to the survey instrument and study design-suggesting a combined survey between CARL and press directors instead.

As a result, the research project was abandoned.

\section{Reasons Why the Research Project Failed and Lessons Learned}

The reasons stated by our participant group for opting out of the survey must be acknowledged and will now be examined through a highly reflective lens, and framed as a series of lessons learned. Each of the lessons are interrelated, however they will be explored separately in order to clearly articulate cause and effect, where possible, as well as practical approaches or things we would do differently a second time around.

Lesson \# 1: Before you begin, understand the landscape and take a balanced approach.

The academic publishing and scholarly communications landscape, 
both in Canada and internationally, is undergoing pervasive change driven by the ongoing impact of digital technology in streamlining research processes and dissemination workflows as well as evolving financial and access models.

Aligned to this, shortly prior to the distribution of the survey, the Association of Canadian University Presses / Association des Presses Universitaires Canadiennes (ACUP) released a report that acknowledged the near-term commitment of Canadian research funding agencies to making open access a condition of funding support. ${ }^{3}$ Beyond this, taking a highly practical and analytical approach, the report clearly articulates a number of financial and other considerations envisaged by this group as a result, for example, switching to an open access business model for monographs, similar to those currently in place for journal articles. ACUP estimated that the impact of a one-year embargo prior to making a manuscript open access would “...reduce year 1 sales by $25 \%$ and years $2-5$ sales by $50 \%$ [and] will have a minimum financial impact of at least $40 \%$ and as much as $50 \%$ of sales revenues."

Academic libraries (often directly engaged in implementing services to enable compliance with funders' open access policies), are keenly aware of the issues associated with the "gold" open access business model that has evolved. Authors can opt to pay an article processing charge (APC) to provide open access to their article, while libraries continue to pay a subscription fee for the journal.

The survey instrument included quantitative and qualitative questions, including an invitation to provide financial information about revenues and other funding support. The survey also included questions about open access publishing and collaborations between libraries and presses. There was an opportunity for presses, only in opting to undertake an optional follow-up interview, to identify any concerns they had with an "open" or other alternative publishing model(s) and therein propose possible solutions to those concerns. 
Beyond this, the wording of our survey invitation framed the study as follows:

The Canadian Association of Research Libraries' (CARL) Open Access Working Group...is interested in investigating possible new [emphasis added] publishing models for Canadian University Presses and Joint University/Library Presses at Canadian academic institutions....

Words carry weight and meaning; the use of the word "new" implies that the existing or "old" publishing models are in need of review and/ or replacement by an alternative. For many university presses, their existing business models have served and continue to serve them well. They may have also felt implied pressure to engage with a model that was not currently viable.

What we might do differently next time:

- In seeking to address seminal issues and ask "hard" questions, take a much more balanced approach and ask those questions of all stakeholders in a structured way in the survey.

- Avoid misplaced use of the word "new." This carelessly chosen word may have rendered the survey null and void in the minds of some of the intended participants even before they clicked on the link to participate. In this way, position the survey more neutrally.

- Timing is everything! Align the investigation and the questions posed in the survey more closely to the issues identified in the 2015 ACUP report, released immediately prior to the survey.

- Invite the association to draft and/or review the questions (see lesson 2, below), fostering an opportunity for collaboration and potentially leveraging uptake. 
Lesson \# 2: If you want to achieve a shared vision, you should take a collaborative / partnership approach from the outset.

One of the reasons Canadian university press directors were reluctant to participate in the survey was that they had not been involved as partners in the creation of the survey.

Building on lesson 1, a second lesson that may be drawn from this is that we could have taken a collaborative approach with our core stakeholders by designing the research study as a balanced partnership, including proportional representation from each core segment, including university presses and library presses. The original research group was made up principally of academic librarians. As a result we failed to give those who justifiably claim an overarching stake in this industry-university press directors-an equal and proportional voice in determining the tenets of any future-scape study.

Affirming this, in a recent statement in response to the Canadian Scholarly Publishing Working Group Final Report, ACUP's support in principle to the working group's recommendation to "establish a shared vision, principles and goals that can act as a framework for advanced, robust, sustainable, collaborative models for the widest dissemination of the Canadian scholarly record." 5 They also state that:

a move towards increased openness for monograph publishing requires a full recognition of the status of publishers as necessary scholarly infrastructure fulfilling a public mandate, which will require substantive, continuing investment to support high quality publishing. ${ }^{6}$

What we might do differently next time:

- Develop the research project as a thoroughly joint and proportionally representative undertaking between academic libraries and university presses. 
Lesson \# 3: Communicate your study objectives clearly to your intended survey participants.

The research group defined the following project objectives:

1. Gather practical feedback from university presses on current publishing models, processes, and practices.

2. Learn more about the types of "open access" publishing models currently available to Canadian authors via both university presses as well as joint university press and library collaborations.

3. Establish the most effective business models and practices that could potentially be successfully implemented by other Canadian presses and/or universities, supporting a comprehensive and economically viable transition to open access publishing in Canada [emphasis added].

4. Produce a set of practical and workable recommendations towards the development of new and ongoing collaboration between libraries and university presses supporting viable economic models, shared goals and practices for the effective dissemination of knowledge and scholarship in a changing and increasingly open scholarly ecosystem.

These objectives were embedded in the survey invite as a link labeled "About the Study" and located near the bottom of the body of the email text, which included important, but perhaps administrative details such as the names of the researchers and information about anonymity and confidentiality.

What we might do differently next time:

- Re-frame the objectives of the study in a way that enables us to learn about existing models, processes, and practices (objective 1 and 2) and establish their relative effectiveness to inform recommendations going forward (objectives 3 and 4) while not specifically seeking recourse towards a "viable transition to open 
access publishing in Canada.” This misplaced emphasis towards "open" will be explored further in lesson 4, below.

- Details matter: communicate the objectives to the participant group in a much more prominent way, perhaps in the body of the email invitation text rather than via an embedded link located at the bottom of the invitation.

Lesson \# 4: Don't make assumptions.

Operating under the auspices of the publicly funded university, academic libraries and librarians are directly accountable to institutional goals to maximize research dissemination and reach of outputs funded by the public purse. The principle of "openness" in the delivery of and access to the research literature and outputs, in all their forms, where possible, remains intrinsic to the mission of academic libraries. However, the notion of open-ness has been supplanted by "open access," which, as an evolving model of publishing, has become increasingly synonymous with the APC business model (see above). This model may be unviable and unsustainable both for libraries (who continue to pay for journals on behalf of authors) and for many smaller publishers (who feel their revenue streams have become increasingly vulnerable to market forces, and competition from a small number of very large commercial publishers). Both the survey invitation and the study objectives reference the term "open access."

What we might do differently next time:

- Avoid misplaced assumptions towards "open-ness," often synonymous with "open access" so as to remove any possible bias towards a particular business model and align the survey questions to explore all potential models as a way to legitimately 
identify opportunities for the future.

- While this geographically dispersed research group invested significant hours collaboratively drafting the mechanics of the study, such as the literature review and the survey questions, we could have paid closer attention to the nuances of capturing the perspectives of a diverse and cross-sectoral group of stakeholders in a transparent and objective manner.

\section{Conclusion}

While the original research project "failed," it offers invaluable lessons, both for the project group and others considering effective research design methodologies, including the importance of clear communication and an unbiased approach.

Perhaps more critically, this experience highlights the importance of partnerships and/or effective engagement and outreach-depending on the project objectives and the nature (demographics, perspectives, etc.) of the participant group(s)-as a means to ensure the proactive involvement of all players when designing survey research. While this more collaborative approach to the project goals, methodology, and design may have extended the original scope and timeline for the project, doing so would have enabled all stakeholders to meaningfully forge a shared vision and values in building resources and infrastructure to support publishing initiatives.

To this end, in July 2016 CARL convened a multi-stakeholder Canadian Scholarly Publishing Working Group (CSPWG) ${ }^{7}$ with representatives from university presses, research libraries, publishers, education and industry groups, a federal funding agency, and several researchers. The group was charged with developing a framework for "robust, sustainable, collaborative models" for dissemination of research outputs and released its final report in July 2017. 


\section{Further Reading}

Andres, Lesley. Designing \& Doing Survey Research. London: SAGE Publications, 2012. doi: 10.4135/9781526402202.

Whitehead, Martha, and Brian Owen. Canadian Universities and Sustainable Publishing (CUSP): A White Paper. Canadian Association of Research Libraries. February 22, 2016. http://www. carl-abrc.ca/wp-content/uploads/2016/04/Can_Univ_Sustainable_ Publishing_2016.pdf.

\section{Endnotes}

1. The CARL Open Access Working Group members were: K. Jane Burpee, associate librarian, research enterprise and scholarly communication, University of Guelph; Bobby Glushko, scholarly communications and copyright librarian, University of Toronto; Inba Kehoe, copyright and scholarly communication librarian, University of Victoria; Pierre Lasou, spécialiste en ressources documentaires, Université Laval; Louise McGillis, associate university librarian, Grenfell and Harlow Campuses, Memorial University; Pat Moore, system librarian-digital projects and technologies, Carleton University; Diane Sauvé, directrice, soutien à la réussite, à la recherche, et à l'enseignement, Université de Montréal; Michael Shires, collection development and liaison librarian, Dr. John Archer Library, University of Regina; Ann Smith, university librarian (acting), Vaughan Memorial Library, Acadia University; Victoria Volkanova, responsable du dossier du libre accès à la recherche, Université de Moncton; and Elizabeth Yates, liaison/scholarly communication librarian, James A. Gibson Library, Brock University.

2. The AAUP conducted two recent surveys directly related to this project: Press and Library Collaboration Survey: Final Report, Association of American University Presses, February 13, 2013, http:// www.aaupnet.org/resources/for-members/data-collection-andanalysis/library-press-collaboration-survey; and Sustaining Scholarly Publishing: New Business Models for University Presses: A Report of 
the AAUP Task Force on Economic Models for Scholarly Publishing, Association of American University Presses, March 2011, http:// www.aaupnet.org/policy-areas/future-of-scholarly-communications/ task-force-on-economic-models-report.

3. Monograph Publishing in an Open Access Context, Association of Canadian University Presses, January 2014, http://www.acup.ca/ wp-content/uploads/2014/03/ACUP-report-open-access.pdf.

4. Monograph Publishing in an Open Access Context, 23.

5. "ACUP / APUC Statement in Response to the Canadian Scholarly Publishing Working Group Final Report," Association of Canadian University Presses, July 4, 2017, http://www.acup.ca/2017/07/04/ acup-apuc-statement-in-response-to-the-canadian-scholarlypublishing-working-group-final-report/.

6. Canadian Scholarly Publishing Working Group, Canadian Scholarly Publishing Working Group: Final Report, July 2017, 2, at http://www.carl-abrc.ca/wp-content/uploads/2017/07/ CSPWG_final_report_EN.pdf.

7. Canadian Scholarly Publishing Working Group: Final Report.

(C) 2017 Rosarie Coughlan, Geoffrey Brown, Robert Glushko, Inba Kehoe

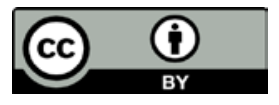

This article is licensed under a Creative Commons Attribution 4.0 International License. To view a copy of this license, visit http:// creativecommons.org/licenses/by/4.0/.

To cite this article: Rosarie Coughlan, Geoffrey Brown, Robert Glushko, Inba Kehoe. "A Quest to Survey Library and University Press Collaborations in Canada: A Case Study in Research Approach and Design." Research Library Issues, no. 292 (2017): 16-26, https://doi. org/10.29242/rli.292.4. 
Copyright of Research Library Issues is the property of Association of Research Libraries and its content may not be copied or emailed to multiple sites or posted to a listserv without the copyright holder's express written permission. However, users may print, download, or email articles for individual use. 